University of Nebraska - Lincoln

DigitalCommons@University of Nebraska - Lincoln

\title{
Water infiltration and surface-soil structural properties as influenced by animal traffic in the Southern Piedmont USA
}

\author{
Alan J. Franzluebbers \\ USDA-Agricultural Research Service, alan.franzluebbers@ars.usda.gov \\ John A. Stuedemann \\ USDA-Agricultural Research Service \\ Dorcas H. Franklin \\ USDA-Agricultural Research Service
}

Follow this and additional works at: https://digitalcommons.unl.edu/usdaarsfacpub

Franzluebbers, Alan J.; Stuedemann, John A.; and Franklin, Dorcas H., "Water infiltration and surface-soil structural properties as influenced by animal traffic in the Southern Piedmont USA" (2011). Publications from USDA-ARS / UNL Faculty. 1486.

https://digitalcommons.unl.edu/usdaarsfacpub/1486

This Article is brought to you for free and open access by the U.S. Department of Agriculture: Agricultural Research Service, Lincoln, Nebraska at DigitalCommons@University of Nebraska - Lincoln. It has been accepted for inclusion in Publications from USDA-ARS / UNL Faculty by an authorized administrator of DigitalCommons@University of Nebraska - Lincoln. 


\title{
Water infiltration and surface-soil structural properties as influenced by animal traffic in the Southern Piedmont USA
}

\author{
Alan J. Franzluebbers*, John A. Stuedemann, and Dorcas H. Franklin \\ USDA-Agricultural Research Service, 1420 Experiment Station Road, Watkinsville, GA 30677, USA. \\ *Corresponding author: alan.franzluebbers@ars.usda.gov
}

\begin{abstract}
Surface-soil structural condition in perennial pastures is expected to be modified by how forage is (a) harvested through haying or grazing and (b) stimulated through source of nutrients applied, as well as by compactive forces, e.g., grazing cattle or hay harvest machinery. Changes in surface-soil condition can affect hydrologic processes that have important implications for plant growth, greenhouse gas emissions and off-site water quality. We determined the effects of harvest management and nutrient source on the rate of ponded water infiltration and penetration resistance in a bermudagrass [Cynodon dactylon (L.) Pers.]/tall fescue (Lolium arundinaceum Schreb. S.J. Darbyshire) pasture on a Typic Kanhapludult in Georgia. During a period when soil was wet (61\% water-filled pore space), the rate of water infiltration was $2.8 \pm 1.5$ times greater when forage was left unharvested as when hayed or grazed (mean \pm standard deviation among nine nutrient source $\times$ harvest management comparisons). During a subsequent period, when soil was dry ( $28 \%$ water-filled pore space), the rate of water infiltration followed the same treatment pattern, but was not statistically different among harvestmanagement practices $(1.5 \pm 0.4$ times greater between unharvested and other systems). Penetration resistance of the surface at $10 \mathrm{~cm}$ depth followed the order: unharvested $(62 \mathrm{~J})<$ hayed $(100 \mathrm{~J})<$ low grazing pressure $(119 \mathrm{~J})<$ high grazing pressure $(137 \mathrm{~J})$. Water infiltration during the wet period was negatively related $(P \leqslant 0.01)$ to soil-water content $(r=-0.57)$, penetration resistance at $0-10 \mathrm{~cm}$ depth $(r=-0.50)$ and bulk density at $3-6 \mathrm{~cm}$ depth $(r=-0.53)$, but was positively related to surface residue $\mathrm{C}(r=0.47)$ and soil organic $\mathrm{C}$ concentration at $12-20 \mathrm{~cm}$ depth $(r=0.42)$. These results suggest that complex soil physical (i.e., aggregation, penetration resistance and infiltration) and biological (i.e., plant growth, surface residues and soil organic matter) interactions occur in pastures. We conclude that well-managed grazing systems with excellent ground cover should have adequate hydrologic condition to promote pasture productivity and limit environmental contamination from runoff. Further work is needed to understand the linkages between field- and watershed-scale hydrology in perennial pastures and their implications on water quality.
\end{abstract}

Key words: bulk density, compaction, pasture management, penetration resistance, soil organic carbon, surface residue

\section{Introduction}

Environmental quality and sustainability of agricultural systems are highly dependent on adequate soil functions. Some critical soil functions are to receive and recycle water, to support vigorous plant communities and to cycle nutrients without loss to the environment. Surface-soil characteristics are of particular importance, not only in affecting the environmental quality of a location but also for determining the environmental quality of neighboring ecosystems if runoff and gaseous emissions are high. Surface cover is an important determinant of how rainfall is partitioned into infiltration and runoff ${ }^{1}$. Humid-zone pastures generally have excellent surface cover, but still may have significant water runoff due to high soil water content or surface compaction with traffic from grazing animals (present whether soil is dry or wet). Since pastures are seldom tilled, nutrients and organic matter can accumulate at the soil surface, and therefore, runoff from pastures can be a threat to water quality ${ }^{2}$. However, high water infiltration allows nutrients accumulating at the surface of undisturbed soil to percolate into the rooting zone of pasture plants for efficient utilization and recycling. Surprisingly, relatively few data are available to assess the impact of how forage management might alter water infiltration in soils of the warm, humid region of the southeastern USA.

When forage is reduced in vigor due to high grazing pressure, the protective plant cover thins and various sized 
patches of bare ground are exposed, leading to low residue cover, compaction, and surface sealing during drying and wetting events, thereby reducing water infiltration and increasing runoff. In Texas, on a silty clay soil, the amount of surface ground cover (both living and dead organic material) was an excellent predictor of water infiltration rate $^{3}$. In Pennsylvania, on clay loam and sandy loam soils, water infiltration was also positively related to surface ground cover and negatively related to cattle grazing intensity ${ }^{4}$. In a review of how animal grazing affects water infiltration, Greenwood and McKenzie ${ }^{1}$ cited several studies documenting how moderate to heavy grazing pressure reduced water infiltration compared to ungrazed or lightly grazed treatments. Trimble and $\mathrm{Mendel}^{5}$ stated: 'on uplands, heavy grazing compacts the soil, reduces infiltration, increases runoff, and increases erosion and sediment yield'. Clearly there is a need to quantify pasturesurface condition, whether forage is grazed or not, when assessing water infiltration.

The impact of grazing on surface-soil structural condition has not been evaluated in great detail in the southeastern USA. The results of the few studies are reviewed here. In a bermudagrass/tall fescue hayfield in the Piedmont of Georgia, water runoff volume, time to runoff and nutrient loss were not statistically affected whether surface soil was aerated or not ${ }^{6}$. In a grazed bermudagrass/ tall fescue pasture in the Piedmont of Georgia, water runoff volume (13\% of rainfall) was not affected whether pastures were grazed continuously or rotationally ( 3 days grazed and 21 days rested) $)^{7}$. During a total of 4 years of this same study, water runoff volume was $15 \pm 4 \%$ of rainfall that occurred in $23 \pm 5$ events per year ${ }^{8}$.

We have been investigating the effects of harvest and nutrient-source treatments on various soil, plant and animal responses in the Piedmont of Georgia to understand the relationships between productivity and conservation. During the first 4 years, we found that soil bulk density was lower in the $0-2 \mathrm{~cm}$ depth when grazed than when ungrazed, but was greater in the $2-4 \mathrm{~cm}$ depth when grazed than when ungrazed, resulting in no difference when summed for the $0-6 \mathrm{~cm}$ depth ${ }^{9}$. We continued the evaluation of this experiment for 12 years and hypothesized that surface-soil structural conditions could have been altered by the presence or absence of grazing cattle. Our objective was to evaluate water infiltration and penetration resistance as indicators of animal impact on surface-soil properties and compare these indicators with associated changes in bulk density, soil organic $\mathrm{C}$, surface residue $\mathrm{C}$ and $\mathrm{N}$, and ground cover.

\section{Materials and Methods}

\section{Site characteristics}

A 15-ha upland field $\left(33^{\circ} 22^{\prime} \mathrm{N}, 83^{\circ} 24^{\prime} \mathrm{W}\right)$ in the Greenbrier Creek subwatershed of the Oconee River watershed near Farmington, GA had previously been conventionally cultivated with various row crops for several decades prior to grassland establishment by sprigging of 'Coastal' bermudagrass in 1991. From 1994 to the end of summer in 1998 , bermudagrass was the dominant forage ${ }^{10}$. 'Georgia 5' tall fescue was drilled (approx. $25 \mathrm{~kg}$ pure live seed ha ${ }^{-1}$ ) directly into existing bermudagrass sod during November 1998, 1999 and 2000. Abnormally dry winter conditions prevented adequate establishment in 1998 and 1999 , resulting in the need for repeated sowing. By 2005 , tall fescue was $\geqslant 50 \%$ of the botanical composition in all treatments. Long-term mean annual temperature in the area is $16.5^{\circ} \mathrm{C}$, rainfall was $1263 \mathrm{~mm}$ and potential evapotranspiration was $1029 \mathrm{~mm}$, based on the Thornthwaite equation. Dominant soils at the site are Madison, Cecil and Pacolet sandy loam (fine, kaolinitic and thermic Typic Kanhapludults).

\section{Experimental design}

The experimental design was a randomized, complete block with treatments in a split-plot arrangement in each of three blocks, which were delineated by landscape features (i.e., slight, moderate and severe erosion classes). Main plots were nutrient source $(n=3)$ and split-plots were harvest management $(n=4)$ for a total of 36 experimental units. Grazed paddocks were $0.69 \pm 0.03$ ha. Spatial design of paddocks minimized runoff contamination and facilitated handling of cattle (Bos taurus) through a central roadway. Each paddock contained a $3 \times 4 \mathrm{~m}$ shade, mineral feeder and water trough placed in a line $15-\mathrm{m}$ long at the highest elevation. Unharvested and hayed exclosures $\left(100 \mathrm{~m}^{2}\right)$ were randomly placed side-by-side in paired low- and high-grazing pressure paddocks of each nutrient source at the initiation of the study in 1994.

Nutrient-source treatments were: (1) inorganic only; (2) organic + inorganic mixture; and (3) organic only. From 1994 to 1998, nutrient-source treatments were: (1) inorganic fertilizer as $\mathrm{NH}_{4} \mathrm{NO}_{3}$ broadcast in May and July; (2) crimson clover (Trifolium incarnatum L.) cover crop+ inorganic fertilizer (half of $\mathrm{N}$ assumed fixed and released by clover cover crop during spring and the other half as $\mathrm{NH}_{4} \mathrm{NO}_{3}$ broadcast in July); and (3) chicken (Gallus gallus) broiler litter $\left(5.4 \mathrm{Mg} \mathrm{ha}^{-1} \mathrm{yr}^{-1}\right)$ broadcast in May and July. Nutrient-source treatments were modified after the first 5 years of management. Fertilizer application was targeted to supply $200 \mathrm{~kg} \mathrm{Nha}^{-1} \mathrm{yr}^{-1}$ during the first 5 years and targeted to supply $270 \mathrm{~kg} \mathrm{Nha}^{-1} \mathrm{yr}^{-1}$ during the next 7 years (see Franzluebbers and Stuedemann ${ }^{11,12}$ for application details). From 1999 to the end of summer 2005, the three nutrient-source treatments were: (1) inorganic fertilizer as $\mathrm{NH}_{4} \mathrm{NO}_{3}$ broadcast in three applications in February-April, May-July and September-November; (2) single application of broiler litter $\left(\sim 2.7 \mathrm{Mg} \mathrm{ha}^{-1} \mathrm{yr}^{-1}\right)$ broadcast in February-April and supplemented with inorganic fertilizer as $\mathrm{NH}_{4} \mathrm{NO}_{3}$ broadcast in May-July and September-November; and (3) multiple applications of 


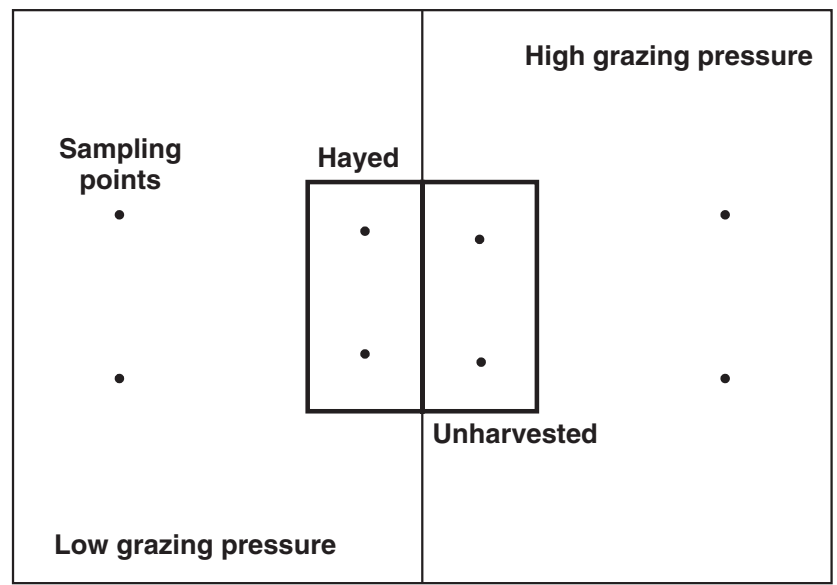

Figure 1. Schematic diagram showing relative location of infiltration rings and penetration resistance sampling points in one nutrient-source treatment that contained hayed and unharvested exclosures and adjacent low and high grazing pressure paddocks.

broiler litter broadcast three times in February-April, May-July and September-November $\left(\sim 8.1 \mathrm{Mg} \mathrm{ha}^{-1} \mathrm{yr}^{-1}\right)$.

Harvest management regime consisted of: (1) unharvested biomass (cut and left in place at the end of growing season during years 1-5 and left unmanaged during years 6-12, except for an occasional woody plant removal); (2) low grazing pressure targeted to maintain $3.0 \mathrm{Mg} \mathrm{ha}^{-1}$ of standing forage after grazing; (3) high grazing pressure targeted to maintain $1.5 \mathrm{Mg} \mathrm{ha}^{-1}$ of standing forage after grazing; and (4) hayed monthly to remove above-ground biomass at 5-cm height. Yearling Angus steers grazed paddocks during a 140-day period from mid-May until early October during years 1-5 (mean body weight of $212 \mathrm{~kg}$ and mean stocking density of 5.8 and 8.7 steers ha $^{-1}$ in low and high grazing pressure treatments, respectively). Grazing was extended into spring (March to May) and autumn (mid-October to early January) during years 6-12 with the presence of tall fescue. Grazing did not typically occur from mid-January to mid-March.

\section{Sampling and analyses}

Single-ring water infiltration ${ }^{13}$ was determined during two separate sampling events in March and April 2006 from duplicate $30-\mathrm{cm}$-diameter steel rings placed approximately $7 \mathrm{~m}$ apart within an experimental unit (Fig. 1). Since both hayed and unharvested exclosures were adjacent to each other, distance between rings was also about $7 \mathrm{~m}$ apart between these treatments. Rings in adjacent grazed paddocks were approximately $15 \mathrm{~m}$ from rings in hayed and unharvested exclosures. This arrangement minimized some soil variations that were expected within large grazed paddocks (e.g., soil texture, cattle paths, etc.). Water (with blue dye added for better visualization) was delivered to rings via a Mariotti siphon system using a 20-liter graduated vessel to monitor quantity ${ }^{13}$. Volume readings were recorded at 10-min intervals for $1 \mathrm{~h}$. A water head of approximately $5 \mathrm{~cm}$ was maintained inside each ring. Recharge of vessel with additional water was needed periodically. From cumulative water infiltrated from 10 to $60 \mathrm{~min}$, we found that a linear regression provided a best fit in most cases $\left(r^{2}=0.97 \pm 0.01\right.$ among estimates in March; $r^{2}=0.99 \pm 0.01$ among estimates in April), and therefore, we determined the intercept [designated as macropore filling $(\mathrm{mm})$; functionally derived as the rapid entry of water filling open pores in surface soil, as well as saturation of large matric potential gradient during the first $10 \mathrm{~min}$; analogous to the expression of sorptivity $\left(\mathrm{mm} \mathrm{min}^{-\frac{1}{2}}\right)^{13}$ ] and slope [designated as infiltration rate $\left(\mathrm{mm} \mathrm{min}^{-1}\right)$ ] for each measurement event $[n=144$ ( 3 nutrient sources $\times 4$ harvest management regimes $\times 3$ replications $\times 2$ subsamples $\times 2$ periods)]. No prewetting of soil occurred, and therefore, soil with low antecedent moisture would be expected to have greater initial rate of infiltration due to macropore filling, but similar steady-state rate of infiltration as wet soil. Again, 'macropore filling' encompasses a combination of filling large voids in the soil matrix and saturating capillarity towards drier soil in the near surface.

Small, in-field runoff collectors $(0.3 \times 0.76 \mathrm{~m})^{14}$ were installed only in low grazing pressure paddocks with inorganic only and organic only nutrient sources for analysis of runoff occurrence from December 1999 to December 2004. A total of 20 runoff collectors in six paddocks were used to determine occurrence of runoff $(0=$ no runoff; $1=$ runoff $)$. Rainfall was recorded on-site with a data logger. A rainfall event was defined as daily rainfall $>1 \mathrm{~mm}$ and ending whenever rainfall did not occur after $08: 00 \mathrm{~h}$ the following morning. Rainfall events lasted 1-3 days. Frequency distribution of rainfall events was determined from categories of 1-10, 10-20, 20-30, 30-40, $40-50$ and $>50 \mathrm{~mm}$. Occurrence of runoff was tested for significance among rainfall event classes and between nutrient-source treatments from the likelihood-ratio statistic using Type 3 source of error.

Penetration resistance was determined in March 2006 at locations $\sim 1 \mathrm{~m}$ from infiltration rings. An impact penetrometer with a 2-kg hammer was dropped 0.74-m distance repeatedly onto a $2.03-\mathrm{cm}$-diameter cone with a $30^{\circ}$ tip $^{15}$. The number of strikes required to reach a depth of 10, 20 and $30 \mathrm{~cm}$ was recorded. Each strike contained the equivalent kinetic energy of $14.5 \mathrm{~J}$. Soil water content was determined at the same time at $0-20-\mathrm{cm}$ depth with time-domain reflectrometry (Field Scout TDR-300, Spectrum Technologies Inc., Plainfield, IL).

Surface residue and soils were sampled in January/ February 2006 and results were presented in detail elsewhere ${ }^{16}$. Surface residue was a composite of eight $0.04-\mathrm{m}^{2}$ areas randomly selected within each of three zones within grazed paddocks (i.e., $0-30,30-70$ and $70-100 \mathrm{~m}$ distances from livestock shades) and from one zone in each exclosure. Following the removal of vegetation above a height of $\sim 4 \mathrm{~cm}$, surface residue, including plant stubble, was cut to the mineral surface with battery-powered hand 


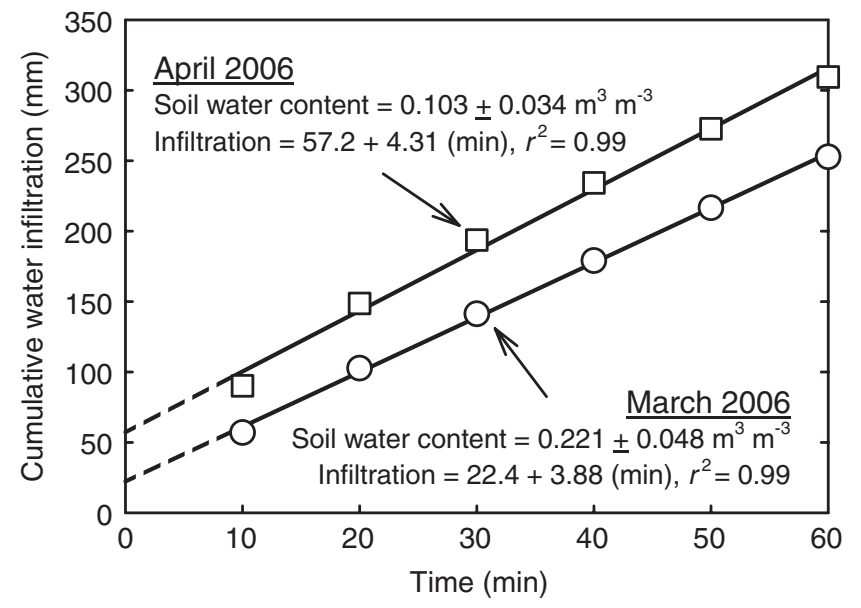

Figure 2. Mean water infiltration across treatments and replicates during the March and April sampling periods at the grassland site near Farmington, GA.

shears, bagged, dried at $55^{\circ} \mathrm{C}$ for several days and ground to $<1 \mathrm{~mm}$. A single 4-cm-diameter soil core was collected from under each of the eight residue sampling sites and composited. Soil bulk density was calculated from the oven-dried soil weight $\left(55^{\circ} \mathrm{C}, 72 \mathrm{~h}\right)$ and pooled-core volume $\left(302,302,603\right.$ and $804 \mathrm{~cm}^{3}$, respectively) from depths of $0-3,3-6,6-12$, and $12-20 \mathrm{~cm}$. Surface residue and soil were analyzed for total $\mathrm{C}$ and $\mathrm{N}$ with dry combustion.

Ground cover was determined in June 2005 from visual inspection of $0.25 \mathrm{~m}^{2}$ areas by an experienced technician of the percent basal area (minimum of 5\% units) of the categories, Coastal bermudagrass, common bermudagrass, tall fescue, weeds and bare ground. Estimates were made from 30 locations per experimental unit in grazed paddocks and 10 locations per experimental unit in exclosures.

Multiple responses within an experimental unit (e.g., two infiltration and penetration resistance estimates in each plot, three residue and bulk density estimates in grazed paddocks) were averaged prior to statistical analysis of the experiment as a split-block with four replications. Transformations were necessary to achieve normality in data distributions, e.g., macropore filling ( $\mathrm{mm})$ and penetration resistance $(\mathrm{J})$ were $\log$-transformed and infiltration rate $\left(\mathrm{mm} \mathrm{min}^{-1}\right)$ and soil water content $\left(\mathrm{m}^{3} \mathrm{~m}^{-3}\right)$ were square-root transformed. Analysis of variance was conducted with nutrient source as main plot $(n=3)$ and harvest management as split-plot $(n=4)$. A priori orthogonal contrasts were constructed to separate treatment effects. Significant differences among treatment means were declared at $P \leqslant 0.05$. Significant correlations among soil and water variables were declared at $P \leqslant 0.01$.

\section{Results and Discussion}

Cumulative water infiltration was nearly linear with time after the first $10 \mathrm{~min}$ (Fig. 2), supporting the simple approach to split the infiltration response into a macropore filling portion during the first $10 \mathrm{~min}$ and a steady-state linear rate of infiltration during the remainder of the hour of evaluation. Wetter antecedent soil condition in March resulted in somewhat lower infiltration than a month later, during which time tall fescue flourished with the springtime flush of growth, thereby effectively removing surface-soil moisture. Rate of water infiltration from 10 to 60 min was on average $0.4 \mathrm{~mm} \mathrm{~min}^{-1}$ greater $(11 \%)$ during the drier period in April, but this was not considered significant based on least-square difference values reported in Table 1. When the rate of water infiltration was calculated using the $20-60 \mathrm{~min}$ period only, the April value was only $7 \%$ greater than the value in March. Macropore filling (intercept in Fig. 2, which accounted for the non-linear infiltration during the first $10 \mathrm{~min}$ ) in the drier period in April was more than double that in March. The difference in macropore filling between March and April of $35 \mathrm{~mm}$ corresponded very well to the difference in soil-water content. With a mean bulk density of $1.35 \mathrm{Mg} \mathrm{m}^{-3}$ at a depth of $12 \mathrm{~cm}$ in 2006 (Table 2), water-filled pore space was 0.61 and $0.28 \mathrm{~m}^{3} \mathrm{~m}^{-3}$ in March and April, respectively, suggesting that the additional $35 \mathrm{~mm}$ of macropore filling in April would have filled the surface $11 \mathrm{~cm}$ of soil.

\section{Wet period in March 2006}

Soil water content was unaffected by nutrient source and harvest management, although some trends emerged for lower water content with organic+inorganic nutrient source than with other nutrient sources $(P=0.09)$ and for greater water content in grazed than ungrazed pastures $(P=0.12)$ (Table 1). The trend for greater water content when pastures were grazed than ungrazed could have been due to greater ground cover (greater basal area that would limit evaporation) and soil organic $\mathrm{C}$ content (increasing water retention) (Table 2) in grazed treatments. Herbage covering the ground could have increased transpiration loss of water, but reduced evaporation. However, transpiration loss in this spring evaluation would have been low due to limited growth at the time of measurement. Macropore filling was also not affected by nutrient source or harvest management regime, suggesting that perennial pasture growth itself may have been more dominating than longterm application of manure on soil macropore development.

The rate of water infiltration was unaffected by nutrient source, but was significantly $(P<0.001)$ affected by harvest anagement regime (Table 1$)$. The infiltration rate was greater when forage was unharvested $\left(6.7 \mathrm{~mm} \mathrm{~min}^{-1}\right)$ than all other harvest management strategies $(2.6-3.2 \mathrm{~mm}$ $\left.\min ^{-1}\right)$. An interactive trend $(P=0.07)$ also occurred, in which there was a larger difference in the infiltration rate between unharvested $\left(9.3 \mathrm{~mm} \mathrm{~min}^{-1}\right)$ and other harvest management regimes $\left(4.0 \mathrm{~mm} \mathrm{~min}^{-1}\right)$ using organic + inorganic nutrient source than between unharvested $(5.4 \mathrm{~mm}$ $\left.\min ^{-1}\right)$ and other harvest management regimes $(3.1 \mathrm{~mm}$ $\min ^{-1}$ ) using organic only nutrient source. Reduced 


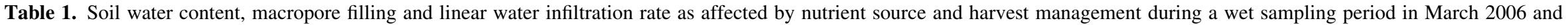
a dry sampling period in April 2006.

\begin{tabular}{|c|c|c|c|c|c|c|c|c|c|c|}
\hline \multirow[b]{3}{*}{ Nutrient source (NS) } & \multirow{3}{*}{$\begin{array}{l}\text { Harvest } \\
\text { management } \\
(\mathrm{HM})\end{array}$} & \multicolumn{6}{|c|}{ March 2006} & \multicolumn{3}{|c|}{ April 2006} \\
\hline & & \multirow{2}{*}{$\begin{array}{l}\text { Soil water } \\
\text { content } \\
\left(\mathbf{m}^{3} \mathbf{m}^{-3}\right)\end{array}$} & \multirow{2}{*}{$\begin{array}{c}\text { Macropore } \\
\text { filling } \\
(\mathrm{mm})\end{array}$} & \multirow{2}{*}{$\begin{array}{c}\text { Infiltration } \\
\text { rate } \\
\left(\mathrm{mm} \mathrm{min}^{-1}\right)\end{array}$} & \multicolumn{3}{|c|}{ Penetration resistance $(\mathbf{J})$} & \multirow{2}{*}{$\begin{array}{l}\text { Soil water } \\
\text { content } \\
\left(\mathbf{m}^{3} \mathbf{m}^{-3}\right)\end{array}$} & \multirow{2}{*}{$\begin{array}{l}\text { Macropore } \\
\text { filling } \\
(\mathbf{m m})\end{array}$} & \multirow{2}{*}{$\begin{array}{c}\text { Infiltration } \\
\text { rate } \\
\left(\mathrm{mm} \mathrm{min}^{-1}\right)\end{array}$} \\
\hline & & & & & $0-10 \mathrm{~cm}$ & $10-20 \mathrm{~cm}$ & $20-30 \mathrm{~cm}$ & & & \\
\hline Inorganic only & Mean & 0.235 & 22 & 2.1 & 107 & 139 & 147 & 0.104 & 51 & 3.9 \\
\hline Organic + inorganic & Mean & 0.187 & 23 & 4.7 & 98 & 141 & 126 & 0.093 & 41 & 4.5 \\
\hline Organic only & Mean & 0.235 & 16 & 3.3 & 96 & 147 & 147 & 0.105 & 52 & 3.6 \\
\hline Mean & Unharvested & 0.201 & 21 & 6.1 & 62 & 127 & 135 & 0.088 & 59 & 5.0 \\
\hline Mean & Low grazing pressure & 0.225 & 20 & 3.0 & 119 & 155 & 154 & 0.103 & 44 & 4.1 \\
\hline Mean & High grazing pressure & 0.231 & 20 & 2.2 & 137 & 154 & 146 & 0.111 & 44 & 3.4 \\
\hline Mean & Hayed & 0.217 & 19 & 2.4 & 100 & 135 & 125 & 0.103 & 45 & 3.4 \\
\hline Inorganic only & Unharvested & 0.220 & 23 & 5.1 & 70 & 133 & 149 & 0.084 & 85 & 4.7 \\
\hline Inorganic only & Low grazing pressure & 0.227 & 22 & 1.9 & 118 & 136 & 151 & 0.095 & 38 & 3.2 \\
\hline Inorganic only & High grazing pressure & 0.264 & 22 & 0.8 & 155 & 164 & 163 & 0.129 & 42 & 4.5 \\
\hline Inorganic only & Hayed & 0.231 & 19 & 1.5 & 101 & 126 & 125 & 0.113 & 52 & 3.2 \\
\hline Organic + inorganic & Unharvested & 0.192 & 26 & 8.9 & 56 & 122 & 132 & 0.093 & 38 & 5.5 \\
\hline Organic + inorganic & Low grazing pressure & 0.191 & 30 & 3.9 & 117 & 150 & 142 & 0.098 & 43 & 4.2 \\
\hline Organic + inorganic & High grazing pressure & 0.192 & 14 & 4.6 & 145 & 166 & 141 & 0.087 & 42 & 4.0 \\
\hline Organic + inorganic & Hayed & 0.195 & 25 & 2.6 & 99 & 130 & 97 & 0.092 & 40 & 4.5 \\
\hline Organic only & Unharvested & 0.217 & 15 & 4.8 & 60 & 126 & 126 & 0.086 & 65 & 5.0 \\
\hline Organic only & Low grazing pressure & 0.260 & 11 & 3.4 & 122 & 180 & 171 & 0.115 & 52 & 5.0 \\
\hline Organic only & High grazing pressure & 0.238 & 28 & 2.1 & 114 & 136 & 137 & 0.120 & 48 & 2.1 \\
\hline Organic only & Hayed & 0.227 & 14 & 3.4 & 101 & 151 & 162 & 0.103 & 44 & 2.7 \\
\hline Source of variation & df & $-\ldots$ & $-\ldots$ & $-\ldots$ & $-\ldots$ & $-\mathrm{Pr}>\mathrm{F}-\mathrm{-}_{-}$ & $-\ldots$ & $-\ldots$ & $-\ldots-1$ & $-\ldots$ \\
\hline $\begin{array}{l}\text { NS1: inorganic versus mixed } \\
\text { and organic only }\end{array}$ & 1 & 0.26 & 0.72 & 0.14 & 0.16 & 0.68 & 0.26 & 0.74 & 0.29 & 0.86 \\
\hline $\begin{array}{l}\text { NS2: organic only versus } \\
\text { inorganic }+ \text { organic }\end{array}$ & 1 & 0.08 & 0.38 & 0.39 & 0.71 & 0.64 & 0.07 & 0.50 & 0.09 & 0.40 \\
\hline HM1: grazed versus ungrazed & 1 & 0.12 & 0.92 & 0.02 & $<0.001$ & 0.004 & 0.05 & 0.18 & 0.37 & 0.54 \\
\hline HM2: unharvested versus hayed & 1 & 0.31 & 0.79 & $<0.001$ & $<0.001$ & 0.38 & 0.44 & 0.22 & 0.27 & 0.14 \\
\hline $\begin{array}{l}\text { HM3: low versus high grazing } \\
\text { pressure }\end{array}$ & 1 & 0.74 & 0.91 & 0.30 & 0.08 & 0.98 & 0.60 & 0.50 & 0.99 & 0.51 \\
\hline $\mathrm{NS} 1 \times \mathrm{HM} 1$ & 1 & 0.97 & 0.88 & 0.38 & 0.89 & 0.77 & 0.97 & 0.92 & 0.17 & 0.71 \\
\hline $\mathrm{NS} 1 \times \mathrm{HM} 2$ & 1 & 0.80 & 0.86 & 0.71 & 0.25 & 0.25 & 0.48 & 0.43 & 0.56 & 0.94 \\
\hline $\mathrm{NS} 1 \times \mathrm{HM} 3$ & 1 & 0.20 & 0.94 & 0.46 & 0.25 & 0.09 & 0.37 & 0.18 & 0.78 & 0.19 \\
\hline $\mathrm{NS} 2 \times \mathrm{HM} 1$ & 1 & 0.60 & 0.40 & 0.72 & 0.29 & 0.41 & 0.38 & 0.28 & 0.71 & 0.80 \\
\hline $\mathrm{NS} 2 \times \mathrm{HM} 2$ & 1 & 0.65 & 0.94 & 0.07 & 0.81 & 0.50 & 0.03 & 0.54 & 0.45 & 0.55 \\
\hline $\mathrm{NS} 2 \times \mathrm{HM} 3$ & 1 & 0.60 & 0.03 & 0.29 & 0.16 & 0.04 & 0.37 & 0.61 & 0.94 & 0.25 \\
\hline
\end{tabular}


Table 2. Characteristics of surface soil as affected by harvest management (mean \pm standard deviation among 3 replication $\times 3$ nutrientsource treatments).

\begin{tabular}{|c|c|c|c|c|}
\hline Harvest management & $\begin{array}{l}\text { Ground cover } \\
(\%)^{I}\end{array}$ & $\begin{array}{l}\text { Surface residue C } \\
\quad\left(\mathrm{Mg} \mathrm{ha}^{-1}\right)^{2}\end{array}$ & $\begin{array}{l}\text { Soil organic C } \\
\left(\mathrm{Mgha}^{-1}\right)^{3}\end{array}$ & $\begin{array}{c}\text { Bulk density } \\
\left(\mathrm{Mg} \mathrm{m}^{-3}\right)^{3}\end{array}$ \\
\hline Unharvested & $79 \pm 11$ & $4.0 \pm 1.4$ & $17.8 \pm 2.3$ & $1.36 \pm 0.07$ \\
\hline Low grazing pressure & $99 \pm 1$ & $2.5 \pm 0.9$ & $21.4 \pm 0.7$ & $1.34 \pm 0.03$ \\
\hline High grazing pressure & $98 \pm 1$ & $1.7 \pm 0.3$ & $21.4 \pm 1.6$ & $1.36 \pm 0.05$ \\
\hline Hayed & $81 \pm 6$ & $1.9 \pm 0.6$ & $15.1 \pm 1.0$ & $1.36 \pm 0.07$ \\
\hline
\end{tabular}

\footnotetext{
${ }^{I}$ Ground cover was estimated from basal area within $0.25 \mathrm{~m}^{2}$ (30 subsamples per plot when grazed and 10 subsamples per plot when ungrazed) in June 2005.

2 Sampled in January/February 2006 from $0.04 \mathrm{~m}^{2}$ areas (eight subsamples per plot).

3 Sampled in January/February 2006 from a 4-cm-diameter core at a depth of $0-12 \mathrm{~cm}$ (eight subsamples per plot).
}

infiltration in grazed compared with unharvested management was likely due to compression of soil at 3-6 cm depth (bulk density was $1.46 \mathrm{Mg} \mathrm{m}^{-3}$ when grazed and $1.39 \mathrm{Mg}$ $\mathrm{m}^{-3}$ when unharvested $)^{16}$. This result was consistent with the majority of literature that shows greater bulk density with increasing animal traffic ${ }^{1}$. The interactive trend between harvest and nutrient source may have been a result of the difference in soil water content between nutrient sources, in which soil water content was lowest when unharvested with organic + inorganic nutrient source (Table 1). As noted from the difference in mean water infiltration between the dry and wet periods, lower soil water content would lead to a greater rate of water infiltration.

Penetration resistance was affected mostly by harvest management and mostly in the surface soil at a depth of $0-10 \mathrm{~cm}$, but some effects also occurred at lower depths (Table 1). At a depth of $0-10 \mathrm{~cm}$, penetration resistance was not affected by nutrient source, but was greater $(P<0.001)$ when grazed $(128 \mathrm{~J})$ than when ungrazed $(81 \mathrm{~J})$, was greater $(P<0.001)$ when hayed $(100 \mathrm{~J})$ than when unharvested $(62 \mathrm{~J})$ and tended to be greater $(P=0.08)$ under high grazing pressure $(137 \mathrm{~J})$ than under low grazing pressure $(119 \mathrm{~J})$. Compared with no animal or tractor traffic when unharvested, mechanical removal of forage as hay reduced surface residue $\mathrm{C}$ (Table 2) and applied surface pressure with tractor wheel traffic [although harvest was with a small tractor of $800 \mathrm{~kg}$ with 18- (front) and 25-(back)cm-wide wheels]. These effects likely caused the difference in penetration resistance between hayed and unharvested treatments. Greater penetration resistance with grazing (Table 1), despite high surface residue $\mathrm{C}$ compared with haying (Table 2), suggests that animal traffic was a significant force that compressed surface soil. The trend for greater penetration resistance with high grazing pressure than with low grazing pressure was further evidence that animal traffic influenced soil firmness.

At a depth of $10-20 \mathrm{~cm}$, penetration resistance was not affected by nutrient source, but was greater $(P=0.004)$ when grazed $(154 \mathrm{~J})$ than when ungrazed $(131 \mathrm{~J})$. Grazing pressure (i.e., low versus high grazing pressure) had an interactive effect with nutrient source $(P=0.04)$ at $10-20 \mathrm{~cm}$; penetration resistance tended to be higher with high grazing pressure than with low grazing pressure using inorganic fertilizer, was similar between grazing pressures using organic + inorganic nutrient source, and was lower with high grazing pressure than with low grazing pressure using organic only nutrient source. This interaction of harvest management with nutrient source is curious and suggests that nutrient availability from organic fertilizer may have positively affected root growth and its influence on stabilizing soil structure. Further research is warranted to better understand this interaction.

At a depth of $20-30 \mathrm{~cm}$, penetration resistance was not affected by nutrient source, but continued to be greater with grazed than with ungrazed systems (Table 1). A significant interaction occurred between nutrient source and harvest management, wherein penetration resistance was lower with haying than unharvested management using organic + inorganic nutrient source, but was greater with haying than unharvested management using organic only as nutrient source $(P=0.03)$.

Resistance of soil to root exploration can be a limitation to plant productivity. Point measurements of penetration resistance should be considered an index of soil resistance to root penetration only, since roots explore soil intraaggregate pores of least resistance, while mechanical devices must penetrate whatever solids and voids are encountered in the insertion path. Soil penetration resistance is a function of bulk density and soil water content, i.e., as bulk density increases and soil water content decreases, penetration resistance increases ${ }^{17}$. Soil penetration resistance on silt loam and silty clay loam soils at a depth of $0-10 \mathrm{~cm}$ was occasionally greater with winter grazing of corn stalks in Iowa ${ }^{18}$, as follows. Soil penetration resistance with grazing was $31 \pm 9 \%(n=6)$ greater than without grazing when soil was frozen for only $22 \pm 33 \%$ of the time, but only $13 \pm 6 \%$ greater (not significant) $(n=9)$ when soil was frozen for $72 \pm 41 \%$ of the time $^{18}$.

Since soil water content is known to affect penetration resistance $^{19}$, we tested the relationship between soil water content and penetration resistance within each depth increment. Soil water content significantly influenced penetration resistance only at a depth of $0-10 \mathrm{~cm}$ (penetration resistance $=52 \pm 249 *$ soil water content, $r^{2}=0.11$, 
$P=0.004$ ), although there was a positive tendency for soilwater content to influence penetration resistance at lower depths also. Adjusting penetration resistance to the mean soil water content of $0.218 \mathrm{~m}^{3} \mathrm{~m}^{-3}$ would have increased the unharvested mean by $4 \mathrm{~J}$ and the hayed mean by $<1 \mathrm{~J}$ and would have decreased the low grazing pressure mean by $2 \mathrm{~J}$ and the high grazing pressure mean by $3 \mathrm{~J}$. None of these changes would have altered the significance or interpretation from the unadjusted means.

\section{Dry period in April 2006}

Soil water content was not affected by nutrient source or harvest management regime during the dry period of evaluation (Table 1). Macropore filling was only different $(P=0.04)$ between unharvested $(73 \mathrm{~mm})$ and hayed $(45 \mathrm{~mm})$ management and there were no significant interactions. This result indicates that macropores were more abundant when grass was completely undisturbed, but this result was inconsistent with the evaluation under wet conditions. The rate of water infiltration was also not affected by nutrient source or harvest management, although the strongest trend $(P=0.11)$ was between unharvested $\left(5.5 \mathrm{~mm} \mathrm{~min}^{-1}\right)$ and hayed management $\left(3.7 \mathrm{~mm} \mathrm{~min}^{-1}\right)$, which was consistent with the effect that occurred during the wetter period in March. The lack of treatment differences during the dry period suggest that soil structural condition may not have been limiting water infiltration at a stage when soil would be most vulnerable to the process of degradation, i.e., if greater runoff were to occur on soil with dry antecedent moisture, then the subsequent process of pasture degradation would certainly follow with lower productivity and loss of nutrients via runoff. However, these results suggest that degradation was likely not occurring and water would still be replenished in soil during vulnerable dry periods.

On pastures managed with near-continuous grazing of bermudagrass/rye (Secale cereale L.) in Georgia, soil penetration resistance was slightly greater $(1.5 \mathrm{MPa})$ when grazed than not grazed by cattle $(1.1 \mathrm{MPa})$, but this may have been partly due to the indirect effect of greater soil water content $\left(134 \mathrm{~g} \mathrm{~kg}^{-1}\right.$ without cattle and $120 \mathrm{~g} \mathrm{~kg}^{-1}$ with cattle $)^{20}$. There was also no difference in steady-state water infiltration between these two pasture systems, similar to our results under dry soil conditions.

On a Typic Cryaquept with $>70 \%$ clay in Finland, steady-state water infiltration was greater in 3.5-year-old pasture (Phleum pretense/Dactylis glomerata) in areas with no visible trampling $\left(1.2 \mathrm{~mm} \mathrm{~min}^{-1}\right)$ than in areas with some trampling $\left(0.5 \mathrm{~mm} \mathrm{~min}^{-1}\right)$, with signs of penetrated hooves $\left(0.3 \mathrm{~mm} \mathrm{~min}^{-1}\right)$, and at drinking sites with destroyed vegetation $\left(0.2 \mathrm{~mm} \mathrm{~min}^{-1}\right)^{21}$. On a nearby coarser-textured soil (6\% clay), steady-state water infiltration was also greater in areas with no visible trampling $\left(2.2 \mathrm{~mm} \mathrm{~min}^{-1}\right)$ than near drinking sites with destroyed vegetation $\left(0.4 \mathrm{~mm} \mathrm{~min}^{-1}\right)$. Deep hoofprints associated with poached pasture near drinking sites are not usually

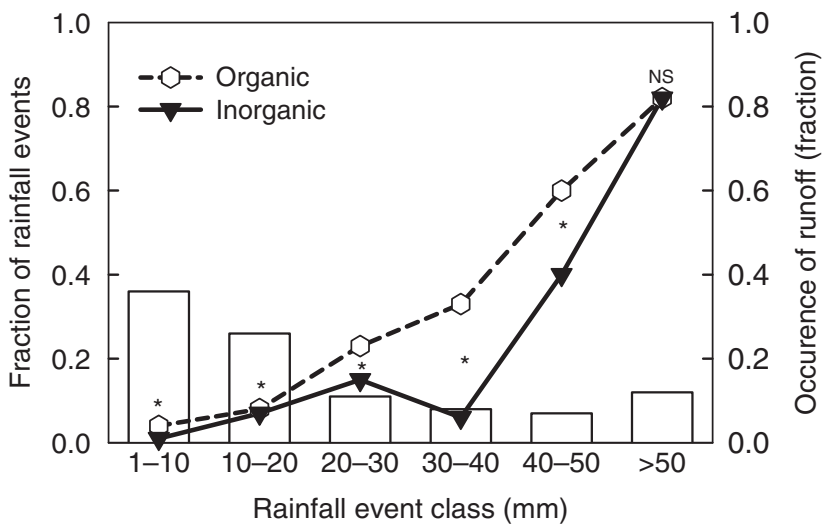

Figure 3. Frequency distribution of rainfall events (bars, left axis) and occurrence of runoff (lines, right axis) from December 1999 to December 2004 at the grassland site near Farmington, GA. Asterisk indicates significant difference $(P \leqslant 0.05)$ in occurrence of runoff between nutrient-source treatments within a rainfall event class. NS indicates no significant difference.

produced immediately upon treading wet soil, but only after a progressive loss of soil strength due to repeated treading $^{22}$. We did not measure infiltration near heavy-use areas, but rather only in the main grazing portion of paddocks to assess generalized effects of cattle on the majority of pasture land area. However, reduced infiltration in heavy-use areas in our study may have also occurred.

\section{Rainfall and occurrence of runoff}

Nearly $40 \%$ of the rainfall events during years 7-11 of this long-term study were small, $\leqslant 10 \mathrm{~mm}$ (Fig. 3). Seventy percent of rainfall events were $\leqslant 20 \mathrm{~mm}$. Precipitation during these 5 years was $89 \pm 26 \%$ of the long-term mean of $1250 \mathrm{~mm}$. Precipitation during year 7 was the lowest at $587 \mathrm{~mm}$ and during year 10 was highest at $1431 \mathrm{~mm}$.

Occurrence of runoff varied strongly with the size of a rainfall event (Fig. 3). With the majority of rainfall events $\leqslant 20 \mathrm{~mm}$, there was $\leqslant 10 \%$ occurrence of runoff. When rainfall events were $20-40 \mathrm{~mm}$, occurrence of runoff rose to $20 \%$. Occurrence of runoff was $50 \%$ with rainfall events of $40-50 \mathrm{~mm}$ and was $82 \%$ with rainfall events $>50 \mathrm{~mm}$. Interestingly, there was significantly greater occurrence of runoff with organic only than with inorganic only as nutrient source in rainfall events that were $<50 \mathrm{~mm}$ in size. The reason for the difference in runoff occurrence with size of rainfall event was obviously due to mass flow of water that could not penetrate soil in a timely manner, but the reason for the difference due to nutrient source was not readily apparent. One possibility is that surface amendment with broiler litter may have increased hydrophobicity of the soil surface (in addition to surface residues), leading to greater incidence of runoff with smaller rainfall events. This possibility deserves greater attention in a more specifically designed research experiment. We did not anticipate this effect in our study, and therefore, were not prepared to address this issue further. 
These data suggest that only a small fraction (15\%) of rainfall events produced widespread occurrence of runoff (>50\% of collectors) under pasture conditions with high surface residue and soil organic $\mathrm{C}$ content (i.e., low grazing pressure). This observation is consistent with observations from long-term watershed studies, in which the majority of sediment loss in conservation-managed agroecosystems is often associated with a few extremely large precipitation events ${ }^{23,24}$. However, these data should not be interpreted as a quantitative measure of runoff volume, since the observations were only of occurrence, whether that occurrence was large or small. Therefore, contrary to agricultural management systems with poor surface condition (e.g., degraded pastures or clean-tilled cropland fields subject to surface sealing), the relatively low occurrence of water runoff suggests that these pastures had infiltration capacities that could handle most rainfall events. Surface sealing is a function of iron oxide and soil organic C concentrations $^{25}$. Kanhapludults in Georgia are prone to surface sealing when exposed to rainfall impact and lack of vegetation cover ${ }^{26}$.

\section{Relationships between variables}

A total of 36 observations (3 nutrient source $\times 4$ harvest management $\times 3$ replications) were tested for correlation among several response variables (water infiltration, macropore filling, penetration resistance, soil water content, bulk density, soil organic $\mathrm{C}$, and surface residue $\mathrm{C}$ and $\mathrm{N}$ ). Only macropore filling, either in the wet period of March or in the dry period of April, was not related to any other variable. The rate of water infiltration during the wet period in March was negatively related $(P \leqslant 0.01)$ to soil water content $(r=-0.57)$, penetration resistance at $0-10 \mathrm{~cm}$ depth $(r=-0.50)$, bulk density at $3-6 \mathrm{~cm}$ depth $(r=$ $-0.53)$ and bulk density at $0-12 \mathrm{~cm}$ depth $(r=-0.42)$. The rate of water infiltration in March was also positively related to surface residue $\mathrm{C}(r=0.47)$ and $\mathrm{N}(r=0.48)$, and to soil organic $\mathrm{C}$ at $12-20 \mathrm{~cm}$ depth $(r=0.42)$. The rate of water infiltration during the dry period in April was only related to bulk density at $0-12 \mathrm{~cm}$ depth $(r=-0.42)$. The rate of water infiltration between March and April, although different in magnitude due to major difference in soil water content, was positively related $(r=0.55)$.

Penetration resistance at $0-10 \mathrm{~cm}$ depth was negatively related to surface residue $\mathrm{C}(r=-0.56)$ and $\mathrm{N}(r=$ $-0.51)$, and bulk density at $0-3 \mathrm{~cm}$ depth $(r=-0.49)$, but positively related to bulk density at $3-6 \mathrm{~cm}$ depth $(r=0.45)$. Penetration resistance at $10-20$ and $20-30 \mathrm{~cm}$ depths was not related to any other soil and water variable, but was highly related to resistance values at different depth increments. Interestingly, penetration resistance at $0-10 \mathrm{~cm}$ depth was positively related to soil organic $\mathrm{C}$ concentration at $0-3 \mathrm{~cm}$ depth $(r=0.61)$ and soil organic $\mathrm{C}$ content at $0-6 \mathrm{~cm}$ depth $(r=0.51)$. We expected a negative relationship between penetration resistance and soil organic $\mathrm{C}$ content, but our results suggest that accumulation of soil organic $\mathrm{C}$ near the soil surface may be due to high density and penetration resistance below $6 \mathrm{~cm}$ depth. Soil organic C was greater in grazed than in ungrazed management systems (Table 2). Although bulk density below 6-cm depth was not negatively affected by grazing ${ }^{16}$, arrangement of pores and altered soil physical structure still may have sufficiently influenced penetration resistance between grazed and ungrazed systems. When data were separated into grazed and ungrazed treatments, there were weak, but negative relationships between penetration resistance and soil organic $\mathrm{C}$ at various depths in both systems. Further research on defining the relationship between soil organic $\mathrm{C}$ and penetration resistance within small depth increments in the soil profile is warranted to better understand how forage management systems might alter soil-surface structural conditions with time.

Correlations between response variables helped to strengthen the reasons for soil structural changes that occurred in this soil as a result of long-term pasture management treatments. For example, the reduction in water infiltration with increasing cattle grazing pressure was due to compression of soil that led to greater penetration resistance in the surface at $10 \mathrm{~cm}$ depth and greater bulk density, particularly at $3-6 \mathrm{~cm}$ depth. Greater surface residue accumulation with grazed and unharvested treatments than with haying led to greater soil organic $\mathrm{C}$ (Table 2), both of which likely assisted with the development of biopores for water infiltration to remain high, even in animal-trafficked soil with grazing. The buffering effect of surface residue and high surface-soil organic matter on the compressive force exerted from frequent cattle traffic in grazed pastures appeared to be significantly strong enough to avoid surface sealing and restriction of water intake. These results are consistent with observations reported by Watts and Dexter ${ }^{27}$, in which integrity of soil aggregates from samples with high soil organic $\mathrm{C}$ (permanent grass) was maintained with mechanical stress, as compared with disintegration of soil aggregates from samples with low soil organic C (arable and clean fallow). In accordance, both water-stable macro-aggregation $\left(>0.25 \mathrm{~mm}, \sim 0.7 \mathrm{~g} \mathrm{~g}^{-1}\right)$ and macro-aggregate stability $\left(\sim 0.9 \mathrm{~g}_{\text {wet }} \mathrm{g}^{-1}\right.$ dry $)$ were high at the end of 4 years in our study ${ }^{28}$.

Our results on grazing impacts on surface-soil structural conditions in bermudagrass/tall fescue pastures in Georgia have some similarities to a study of continuous versus rotational grazing of tallgrass praire in Texas ${ }^{29}$. In both studies, infiltration was greatest and penetration resistance was lowest in ungrazed exclosures. In both studies, bulk density was unaffected by the management system. We did not find differences in soil water content, macropore filling, infiltration rate, penetration resistance or soil organic $\mathrm{C}$ between low and high grazing pressures, but Teague et al. ${ }^{29}$ observed: (a) lower soil water content in heavy-continuous grazing compared with light-continuous and multi-paddock grazing; (b) no difference between treatments in infiltration rate; (c) greater penetration resistance in heavy-continuous grazing compared with light-continuous and multi-paddock 
grazing; and (d) lower soil organic $\mathrm{C}$ in heavy-continuous grazing than light-continuous and multi-paddock grazing. There is a great deal of interest in management-intensive rotational grazing ${ }^{30-32}$, but there are very few studies documenting the quantitative impacts of such systems on surface-soil structural conditions, and therefore, such research is greatly needed to understand its impacts on contemporary environmental issues of soil and water quality, greenhouse gas emissions, and ecosystem structure and function.

\section{Conclusions}

A rather complex arrangement of surface-soil structural conditions developed in this Typic Kanhapludult in response to nutrient source and harvest management. The application of organic nutrients such as broiler litter had little impact on ponded water infiltration and penetration resistance, suggesting that how forage utilized applied nutrients and how harvest mechanisms manipulated forageresidue placement and quality were more important than the source of nutrients, per se. Although water infiltration was lower with grazing and haying than unharvested forage, as expected, this effect was significant only under wetter soil conditions. In addition, soil penetration resistance was greater with increasing grazing pressure. Lack of infiltration differences between grazed and ungrazed systems when soil was dry, suggests that pore connectivity may have been positively influenced by greater soil organic $\mathrm{C}$ in grazed systems, and this consequence may have compensated for the negative influence of greater penetration resistance with animal traffic. Water infiltration in continuously grazed bermudagrass/tall fescue pastures was adequately maintained with low or high grazing pressure compared to haying, despite a firmer soil surface. This effect may have been mediated by high surface residue cover, which prevented soil from sealing. Although not specifically tested here, management-intensive rotational grazing might be expected to also produce similar results between grazed and ungrazed management systems due to its reliance on periodical forage accumulation and subsequent surface residue accumulation. The put-and-take stocking system used in this study is a research tool that acknowledges residual forage mass as a keystone property of pastures, but that creates a continuous and more uniform grazing pressure throughout the year by adjusting stocking rate as necessary to maintain a target forage mass, not by adjusting return interval of a high stocking density. These results have important implications for a pedon-based understanding of hydrologic consequences from the 19 Mha of managed pastures in the warm, humid region of the southeastern USA; namely that well-managed pastures can promote efficient water cycling and control of nutrient runoff into receiving bodies of water. Further research is needed to understand the linkages between field- and watershed-scale hydrology in perennial pastures and their implications on water quality, especially under large, but infrequent storm events that cause the greatest occurrence of runoff.

Acknowledgements. We appreciate the excellent technical support from Steve Knapp, Dwight Seman, Beth Barton and many co-workers throughout the years of this experiment (David Lovell, Robert Sheats, Fred Hale, Eric Elsner, Robert Martin, Devin Berry, Heather Hart and Kim Lyness).

\section{References}

1 Greenwood, K.L. and McKenzie, B.M. 2001. Grazing effects on soil physical properties and the consequences for pastures: A review. Australian Journal of Experimental Agriculture 41:1231-1250.

2 DeLaune, P.B., Moore, P.A. Jr, Carman, D.K., Sharpley, A.N., Haggard, B.E., and Daniel, T.C. 2004. Development of a phosphorus index for pastures fertilized with poultry litter factors affecting phosphorus runoff. Journal of Environmental Quality 33:2183-2191.

3 Thurow, T.L., Blackburn, W.H. and Taylor, C.A. Jr 1988. Infiltration and interrill erosion responses to selected livestock grazing strategies, Edwards Plateau, Texas. Journal of Range Management 41:296-302.

4 Alderfer, R.B. and Robinson, R.R. 1947. Runoff from pastures in relation to grazing intensity and soil compaction. Journal of the American Society of Agronomy 39:948-958.

5 Trimble, S.W. and Mendel, A.C. 1995. The cow as a geomorphic agent $-\mathrm{a}$ critical review. Geomorphology 13:233-253.

6 Franklin, D.H., Cabrera, M.L. and Calvert, V.H. 2006. Fertilizer source and soil aeration effects on runoff volume and quality. Soil Science Society of America Journal 70:84-89.

7 Kuykendall, H.A., Cabrera, M.L., Hoveland, C.S., McCann, M.A., and West, L.T. 1999. Stocking method effects on nutrient runoff from pastures fertilized with broiler litter. Journal of Environmental Quality 28:1886-1890.

8 Pierson, S.T., Cabrera, M.L., Evanylo, G.K., Kuykendall, H.A., Hoveland, C.S., McCann, M.A., and West, L.T. 2001. Phosphorus and ammonium concentrations in surface runoff from grasslands fertilized with broiler litter. Journal of Environmental Quality 30:1784-1789.

9 Franzluebbers, A.J., Stuedemann, J.A. and Wilkinson, S.R. 2001. Bermuda grass management in the Southern Piedmont USA: I. Soil and surface residue carbon and sulfur. Soil Science Society of America Journal 65:834-841.

10 Franzluebbers, A.J., Wilkinson, S.R. and Stuedemann, J.A. 2004. Bermuda grass management in the Southern Piedmont USA: X. Coastal productivity and persistence in response to fertilization and defoliation regimes. Agronomy Journal 96:1400-1411.

11 Franzluebbers, A.J. and Stuedemann, J.A. 2005. Bermuda grass management in the Southern Piedmont USA: VII. Soilprofile organic carbon and total nitrogen. Soil Science Society of America Journal 69:1455-1462.

12 Franzluebbers, A.J. and Stuedemann, J.A. 2009. Soil-profile organic carbon and total nitrogen during 12 years of pasture management in the Southern Piedmont USA. Agriculture, Ecosystems and Environment 129:28-36. 
13 Bouwer, H. 1986. Intake rate: Cylinder infiltrometer. In A. Klute (ed.). Methods of Soil Analysis, Part 1, Physical and Mineralogical Methods. 2nd ed., Agronomy No. 9. American Society of Agronomy and Soil Science Society of America, Madison, WI. p. 825-844.

14 Franklin, D.H., Cabrera, M.L., Steiner, J.L., Endale, D.M., and Miller, W.P. 2001. Evaluation of percent flow captured by a small in-field runoff collector. Transactions of the ASAE 44:551-554.

15 Herrick, J.E. and Jones, T.L. 2002. A dynamic cone penetrometer for measuring soil penetration resistance. Soil Science Society of America Journal 66:1320-1324.

16 Franzluebbers, A.J. and Stuedemann, J.A. 2010. Surface soil changes during twelve years of pasture management in the Southern Piedmont USA. Soil Science Society of America Journal 74:2131-2141.

17 Taylor, H.M. and Gardner, H.B. 1962. Penetration of cotton seedling taproots as influenced by bulk density, moisture content, and strength of soil. Soil Science 96:153-156.

18 Clark, J.T., Russell, J.R., Karlen, D.L., Singleton, P.L., Busby, W.D., and Peterson, B.C. 2004. Soil surface property and soybean yield response to corn stover grazing. Agronomy Journal 96:1364-1371.

19 Busscher, W.J., Bauer, P.J., Camp, C.R., and Sojka, R.E. 1997. Correction of cone index for soil water content differences in a coastal plain soil. Soil and Tillage Research 43:205-217.

20 Tollner, E.W., Calvert, G.V., and Langdale, G. 1990. Animal trampling effects on soil physical properties of two southeastern U.S. Ultisols. Agriculture, Ecosystems and Environment 33:75-87.

21 Pietola, L., Horn, R., and Yli-Halla, M. 2005. Effects of trampling by cattle on the hydraulic and mechanical properties of soil. Soil and Tillage Research 82:99-108.

22 Scholefield, D. and Hall, D.M. 1986. A recording penetrometer to measure the strength of soil in relation to the stresses exerted by a walking cow. European Journal of Soil Science $37: 165-176$.
23 Shipitalo, M.J. and Edwards, W.M. 1998. Runoff and erosion control with conservation tillage and reduced-input practices on cropped watersheds. Soil and Tillage Research 46:1-12.

24 Starr, G.C., Lal, R., Owens, L., and Kimble, J. 2008. Empirical relationships for soil organic carbon transport from agricultural watersheds in Ohio. Land Degradation and Development 19:57-64.

25 Singer, M.J. and Le Bissonnais, Y. 1998. Importance of surface sealing in the erosion of some soils from a Mediterranean climate. Geomorphology 24:79-85.

26 Zhang, X.C. and Miller, W.P. 1996. Physical and chemical crusting processes affecting runoff and erosion in furrows. Soil Science Society of America Journal 60:860-865.

27 Watts, C.W. and Dexter, A.R. 1997. The influence of organic matter in reducing the destabilization of soil by simulated tillage. Soil and Tillage Research 42:253-275.

28 Franzluebbers, A.J., Wright, S.F., and Stuedemann, J.A. 2000. Soil aggregation and glomalin under pastures in the Southern Piedmont USA. Soil Science Society of America Journal 64:1018-1026.

29 Teague, W.R., Dowhower, S.L., Baker, S.A., Haile, N., DeLaune, P.B., and Conover, D.M. 2011. Grazing management impacts on vegetation, soil biota and soil chemical, physical, and hydrological properties in tall grass prairie. Agriculture, Ecosystems and Environment 141:310-322.

30 Beetz, A.E. and Rinehart, L. 2010. Rotational Grazing. National Center for Appropriate Technology, Fayetteville, AR. 12 p. Available at Web site http://www.attra.ncat.org/ attra-pub/rotgraze.html (verified August 5, 2011).

31 Briske, D.D., Derner, J.D., Brown, J.R., Fuhlendorf, S.D., Teague, W.R., Havstad, K.M., Gillen, R.L., Ash, A.J., and Willms, W.D. 2008. Rotational grazing on rangelands: Reconciliation of perception and experimental evidence. Rangeland Ecology and Management 61:3-17.

32 Sollenberger, L.E. and Vanzant, E.S. 2011. Interrelationships among forage nutritive value and quantity and individual animal performance. Crop Science 51:420-432. 